Chirurgia (2019) 114: 29-38

No. 1, January - February

Copyright $@$ Celsius

http://dx.doi.org/10.21614/chirurgia.114.1.29

\title{
The Current Surgical Managemnt of the Parietal Deffects in Patients with Liver Cirrhosis - Options and Limits. Our Experience and Review of Literature
}

\author{
Petrișor Banu ${ }^{1,2}$, Bogdan Socea ${ }^{1,2}$, Alexandru Carâp ${ }^{1,2}$, Ion Motofei ${ }^{1,2}$, Cristian Bălălău ${ }^{1,2}$, Simona Bobic ${ }^{1,2}$, \\ Vlad Constantin ${ }^{1,2}$
}

'General Surgery Department "Sfântul Pantelimon" Emergency Clinical Hospital, Bucharest Romania

${ }^{2}$ General Surgery Department, "Carol Davila" University of Medicine and Pharmacy, Bucharest, Romania

Corresponding author:

Professor Vlad Constantin

General Surgery Department

"Sfântul Pantelimon" Emergency

Clinical Hospital, Bucharest Romania

General Surgery Department,

"Carol Davila" University of Medicine

and Pharmacy, Bucharest, Romania

E-mail: constantindenis@yahoo.com

\section{Rezumat}

Chirurgia actuală a defectelor parietale la cirotic - opțiuni și limite. Experiența noastră și review al literaturii

Introducere: Herniile peretelui abdominal au la pacienții cu ciroză o prevalență semnificativ mai mare față de pacienții non cirotici. Modalitatea de abord chirugical şi momentul operator sunt elemente aflate încă în dezbatere.

Material şi metodă: Am analizat retrospectiv cazurile de hernii operate la pacienți cu ciroză hepatică în Clinica de Chirurgie a Spitalului Clinic "Sf. Pantelimon" din Bucureşti în intervalul Ianuarie 2012 - Decembrie 2016. Din fişele de observație ale pacientilor am reținut analizele de laborator (albuminemie, bilirubinemie, timp de protrombină) şi datele clinice (prezența ascitei şi encefalopatiei) care au permis încadrarea conform claselor Child, precum şi date referitoare la tipul herniei, caracterul de urgență sau electiv al intervenției chirurgicale, tehnica operatorie utilizată şi evoluția postoperatorie. Analiza statistică s-a făcut pe baza testului chi - pătrat.

Rezulate: Dintre cel 65 de hernii operate, 32 au fost ombilicale (49,23\%), 18 inghinale $(27,69 \%), 11$ incizionale $(16,92 \%)$ şi 4 epigastrice (6,15\%). 29 (44,6\%) dintre interventii au fost efetuate programat, iar $36(55,4 \%)$ au avut caracter de urgență. Încadrarea în grupe Child a fost: 24 (36,92\%) Child A, 30 (46,15\%) Child B, 11 (16,92\%) Child C. Morbiditatea postoperatorie a fost de 11 cazuri pentru Child A (45,83\%), 17 pentru Child B $(56,66 \%)$ şi 9 pentru Child C (81,8\%). Mortalitatea a fost 1 caz pentru Child A $(4,16 \%)$, 
4 cazuri pentru Child B (13,33\%) şi 8 cazuri pentru Child C (72,72\%). Cele mai mari rate ale mortalități au fost consemnate la pacienții operați în urgență.

Concluzii: Defectele parietale ale ciroticului pot fi abordate chirurgical cu rezultate satisfăcătoare. Cele mai bune rezulate sunt obținute în cazul pacienților operați electiv şi în stadii compensate ale cirozei. Modalitățile tehnice de rezolvare a acestor hernii sunt sunt atât herniorafiile, cât şi cele care utilizează materialele alloplastice. Pentru pacienții cu ascită, controlul eficient al acesteia condiționează obținerea unor rezultate bune. Intervențiile efectuate în condiții de urgență au cele mai mari rate ale mortalității şi morbidității.

Cuvinte cheie: perete abdominal, hernie, ciroză, ascită

\section{Abstract}

Introduction: The abdominal wall hernias in patients with liver cirrhosis have a significant higher prevalence than those in non- cirrhotic patients. The best surgical treatment option and the optimal operative time still represent a subject of debate.

Material and method: We have retrospectively analyzed the cases of abdominal wall hernias in patients with liver cirrhosis admitted in the Surgical Department of the "Sfântul Pantelimon" Clinical Emergency Hospital from Bucharest, undergoing surgical treatment between January 2012 and December 2016. Data regarding the laboratory results (the serum albumin and bilirubin levels, the Prothrombin Time) and the clinical aspects (the presence of ascites or encephalopathy) that helped establish the grade of the disease according to Child classification system, and, also, the information regarding the type of hernia, the character of the surgical indication (emergency or elective), the surgical technique and the postoperative evolution have been collected from the medical documents of the patients included in the present study. The statistical analysis has been made using the chi- square test.

Results: 32 cases out of the total 65 patients included in the study, that underwent surgical intervention for the treatment of the abdominal wall defects, had umbilical hernia $(49,23 \%), 18$ cases presented with inguinal hernia (27.69\%), 11 with incisional hernia (16.92\%) and 4 with epigastric hernia (6.15\%). 29 patients were subjected to elective surgery (44.6\%) and 36 to emergency surgery $(55,4 \%)$. Regarding the Child classification system used in the present study, 24 patients presented with Child A grade of cirrhosis (36.92\%), 30 with Child B (46.15\%) and 11 with Child C (16.92\%). The postoperative morbidity rate was $45,83 \%$ in Child A group, 56,66\% in Child B group and $81,8 \%$ in Child C group. The mortality rate was $4,16 \%$ in the Child A group (one death), $13.33 \%$ in the Child B group (4 deaths) and $72.72 \%$ in Child $\mathrm{C}$ group (8 cases). The highest mortality rates have been registered in patients that underwent emergency surgical intervention. Conclusions: The parietal defects in patients with liver cirrhosis can be surgically treated with satisfactory outcomes. The best results have been registered in patients with compensated form of the cirrhosis or in cases undergoing elective surgery. The methods used for the surgical treatment of the abdominal wall defects vary from herniorrhaphy to alloplastic techniques. For patients with ascites, a good control of this complication represents an important factor for the favourable postoperative evolution. The emergency surgical interventions are associated with greater risks of morbidity and mortality.

Key words: abdominal wall, hernia, cirrhosis, ascites 


\section{Introduction}

In patients with liver cirrhosis, abdominal parietal hernias occur with a significantly higher prevalence than the general population, reaching about $20 \%$ or even $40 \%$ in the presence of ascites (1).

This is the direct consequence of a cumulative number of factors that these patients present: increased intra-abdominal pressure due to ascites, weakening of the musculature and fascial structures of the abdominal wall on the background of precarious nutritional status, and poor scarring for incisional hernias (2).

The precarious general status and the systemic functional deficits that accompany and worsen the evolution of the patients with liver cirrhosis make the surgical approach of this group of patients a subject of debate, taking into consideration the associated high morbidity and mortality rates. For hernia surgery alone, the risk of postoperative mortality is four times higher in cirrhotic than in non-cirrhotic patients (3).

On the other hand, the presence of the hernia is accompanied by an alteration of the quality of life of the patient through local pain and limitation of the physical activity (4).

The "watch and wait" attitude involves assuming a risk of complications such as strangulation or ulceration, which will require emergency treatment. At the same time, however, emergency surgery in patients with liver cirrhosis also attracts an exponential increase of the complications and mortality rates (5).

These are prerequisites that give rise to controversy that persist in addressing the parietal defecttreatment options of the cirrhotic patients.

Our goal is to define the optimal way of approaching the parietal defects of the cirrhotic patient, both from a technical perspective and in relation to the stage of the cirrhosis or to the clinical presentation of the patients, starting from the experience of our clinic and reviewing the data from the literature.

\section{Material and Method}

We have retrospectively analyzed patients with liver cirrhosis undergoing surgical intervention in the Surgical Department of the Emergency Clinical Hospital from Bucharest, Romania, between January 2012 and December 2016.

Data regarding the laboratory results (the serum albumin and bilirubin levels, the Prothrombin Time) and the clinical aspects (the presence of ascites or encephalopathy) that helped establish the grade of the disease according to Child classification system, and, also, the information regarding the type of hernia, the character of the surgical indication (emergency or elective), the surgical technique and the postoperative evolution have been collected from the medical documents of the patients included in the present study.

The statistical analysis has been made using the chi- square test.

For elective surgery cases, preoperative preparation aimed at optimizing the patient's general condition by correcting the clotting disorders, improving the nutritional status and reducing the volume of the ascites.

Emergency operations were indicated by complications such as strangulation, incarceration or hernia ulceration and peritoneocutaneous fistula with ascetic fluid leakage.

Regarding the technical way of solving the parietal defects, we used both herniorrhaphy and alloplastic procedures.

\section{Results}

The study population included 41 males (63\%) and 24 females (37\%) with ages between 41 and 67 years old, with a mean age of 52, 7 years old. The aetiology of the liver cirrhosis was represented by alcohol for 28 cases $(43 \%)$ or viral infection (B or C) for 37 cases (57\%).

Regarding the Child classification system used in the present study, 24 patients presented with Child A grade of cirrhosis (36.92\%), 30 with Child B (46.15\%) and 11 with Child C (16.92\%) (Fig. 1). 


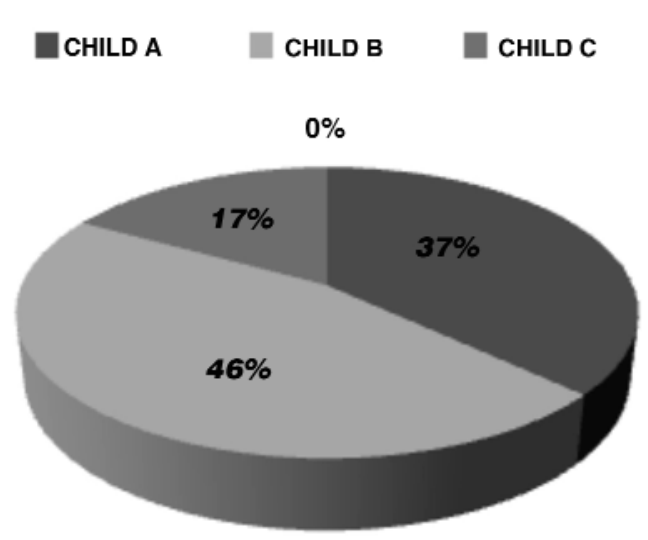

Figure 1. Child classification in the study group

29 patients $(44.6 \%)$ underwent elective surgery and 36 (55.4\%) emergency surgery secondary to complications such as incarceration (13 cases - $20 \%$ ), strangulation (17 cases$26.15 \%$ ) and ulceration (6 cases - 9.23\%).

32 cases out of the total 65 patients included in the study, that underwent surgical intervention for the treatment of the abdominal wall defects, had umbilical hernia (49.23\%), 18 cases presented with inguinal hernia $(27.69 \%), 11$ with incisional hernia $(16.92 \%)$ and 4 with epigastric hernia (6.15\%) (Fig. 2).

Ascites was present in 21 patients (32.3\%). Of these, 12 (18.46\%) underwent elective surgery, taking preoperative reduction in ascitic volume through hyposodic diet, diuretics or repeated paracentesis.

For 39 of the cases, technique of herniorrha- phy was performed. The decision was made taking into consideration the clinical presentation of the hernia and the general condition of the patient. This solution was mainly adopted in emergency interventions, for strangulation or skin ulceration with a degree of contamination, but also in patients with decompensated stages of cirrhosis. 26 cases were solved using alloplastic materials. The polypropylene mesh was placed in a retromuscular plane in 10 patients with umbilical hernias and 5 with incisional hernias. 4 umbilical hernias and 2 incisional hernias were laparoscopically approached. For 5 inguinal hernias, the tension-free Lichtenstein repair was performed (Table 1).

In 3 cases, segmental enterectomy was required due to irreversible lesions caused by strangulation.

The average hospitalization period was 9 days, with net differences between elective cases, where hospitalization was between 2 and 11 days (mean of 4 days), and emergency patients whose length of hospitalization was between 7 and 29 days with an average of 15 days.

Patient progress was followed for 30 days postoperatively. There were 37 postoperative complications $(56.92 \%)\left(\chi^{2}=1.716, \mathrm{df}=1, \mathrm{p}<0.2\right)$ consisting of wound infections, seromas, hematomas; in two cases, the wound dehiscence occurred after umbilical herniorrhaphy, requiring reintervention. The most severe

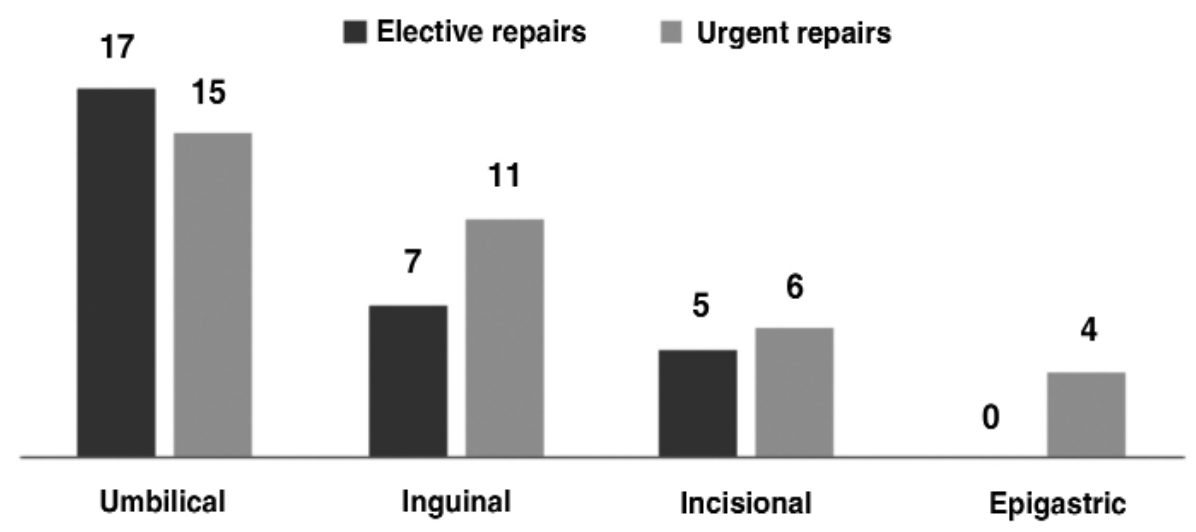

Figure 2. Types of abdominal wall defects in the study group 
Table 1. Surgical techniques used in the study population

\begin{tabular}{lcccc}
\hline & Umbilical hernia & Inguinal hernia & Incisional hernia & Epigastric hernia \\
\hline Herniorrhaphy & 18 & 13 & 4 & 4 \\
\hline Hernioplasty & 14 & 5 & 7 & 0 \\
\hline
\end{tabular}

complications, encephalopathy, worsening of ascites, liver failure or renal failure occurred in emergency patients.

The general mortality rate was 20\% (13 cases). 8 of the deaths were recorded in Child $\mathrm{C}$ and 4 in Child B, one in Child A. $\chi^{2}=18,965$, $\mathrm{df}=1, \mathrm{p}<0.0001$ (Table 2).

In the group of patients with Child A we practiced herniorrhaphy in 6 cases $(25 \%)$ and we used alloplastic materials for 18 cases $(75 \%)$. 13 interventions (54.16\%) were addressed for hernia complications (incarceration 8 cases $33.3 \%$, strangulation $5-20.83 \%$ ); 11 interventions were scheduled (45.83\%). There was a death $(4.16 \%)$ in a strangled umbilical hernia patient with segmentary enterectomy. Of the 11 (45.83\%) postoperative complications recorded in this group (5 wound infections, 3 hematomas and 3 seromas), 7 (53.84\%) were from the emergency surgery group and $4(36.36 \%)$ from the elective surgery group. No hernia recurrence was found.

For patients in Child B stage, 15 surgeries were practiced in emergency (50\%) and 15 elective (50\%). Alloplastic materials were used in 8 situations $(26.66 \%)$. Ascites was present in 12 cases $(40 \%)$ and for those that required elective operations its therapeutic control was practiced through hyposodic diet, diuretic administration and paracentesis. Postoperative peritoneal drainage in the presence of ascites was not performed, given the high risk of a bacterial infection that would significantly increase the postoperative mortality rate.

Postoperative complications occurred in 17 cases $(56.66 \%), 10$ of them undergoing emergency surgery (66.66\%) and 7 elective surgery $(46.66 \%)$. The most severe complications, renal failure, encephalopathy and worsening of ascites occurred in emergency patients. One case needed surgical reintervention because of the postoperative wound dehiscence. There were 4 deaths in this group (13.33\%). There was no recurrence.

Patients in the Child $\mathrm{C}$ group were subjected to emergency surgery in 8 cases $(72.7 \%)$, to elective surgery in 3 cases $(27 \%)$, the technical solution performed being represented by herniorrhaphy. The highest mortality rate was recorded in these cases, $8(72.7 \%)$, all cases being operated under emergency conditions. Complications occurred in 3 cases, the worsening

Table 2. The characteristics of the study population

\begin{tabular}{lcccc}
\hline & CHILD A & CHILD B & CHILD C \\
\hline Number of cases & $24(36.92 \%)$ & $30(46.15 \%)$ & $11(16.92 \%)$ \\
\hline Elective surgery $29(44.6 \%)$ & 11 & 15 & 3 \\
\hline Emergency surgery 36 (55.4\%) & Umbilical & 13 & 15 & 8 \\
\hline Types of hernia & Inguinal & 7 & 19 & 6 \\
& Incisional & 8 & 7 & 3 \\
& Epigastric & 6 & 3 & 2 \\
Surgical technique & Herniorrhaphy & 3 & 1 & 0 \\
& Hernioplasty & 6 & 22 & 11 \\
Morbidity & & 18 & 8 & 0 \\
\hline Mortality & & 11 & 17 & 9 \\
\hline
\end{tabular}


of encephalopathy (1 case) and hepatic failure ( 2 cases). No hernia recurrence was found in the postoperative follow-up interval.

\section{Discussion}

The presence of parietal defects is a pathology often present in patients with liver cirrhosis, but the surgical approach of these patients has been made with reserve.

Analysing 16 consecutive cases of umbilical hernia in cirrhosis undergoing surgery, in 1960, Baron reported a significant mortality rate of $31 \%$ (5 cases), all secondary to cataclysmic digestive haemorrhages due to rupture of the oesophageal varices. It has been assumed that the method used, herniorrhaphy, blocks the collaterals of the portosythematic circulation leading to the increase of the retrograde pressure. These results led to the idea that the hernia surgery in this category of patients is associated with a very high risky of mortality (6).

More recently (2005), Carbonell, in a large cohort study that included 30000 cases, comparing the results of the hernia surgery in patients with cirrhosis with the one in noncirrhotic patients, found unfavorable results for the first category. Thus, the duration of hospitalization for cirrhotic patients is higher (5.4 vs. 3.7 days), with increased morbidity $(16.5 \%$ vs. $13.8 \%$, and significantly higher mortality $-2.5 \%$ vs. $0.2 \%$. These results are mainly the consequence of the comorbidities that the cirrhotic patient presents: heart failure, renal failure, nutritional deficiencies, etc., as well as the fact that a significant percentage of them have undergone emergency surgery (7).

On the other hand, however, there are many other studies that report satisfactory results of the surgical approach in cirrhotic patients with abdominal wall hernias, comparable in some cases to those of the noncirrhotic patients (8-11).

Analysing these results, there are defined some elements that influence the results of the hernia surgery in cirrhotic patients: the presence of ascites, the stage of the liver cirrhosis, the surgical technique used and the elective or emergency character of the intervention.

The presence of ascites is most commonly associated with the presence of umbilical hernia in the cirrhotic patient. Increased abdominal pressure secondary to ascites directly leads to the appearance of the hernia, along with the weakening of the fascial and muscular structures, amid nutritional deficiencies. If the prevalence of the umbilical hernia is $2 \%$ in the general population, in the context of cirrhosis it increases to $20 \%$ or even $40 \%$ in the presence of ascites. For other types of parietal hernia, the presence of ascites per

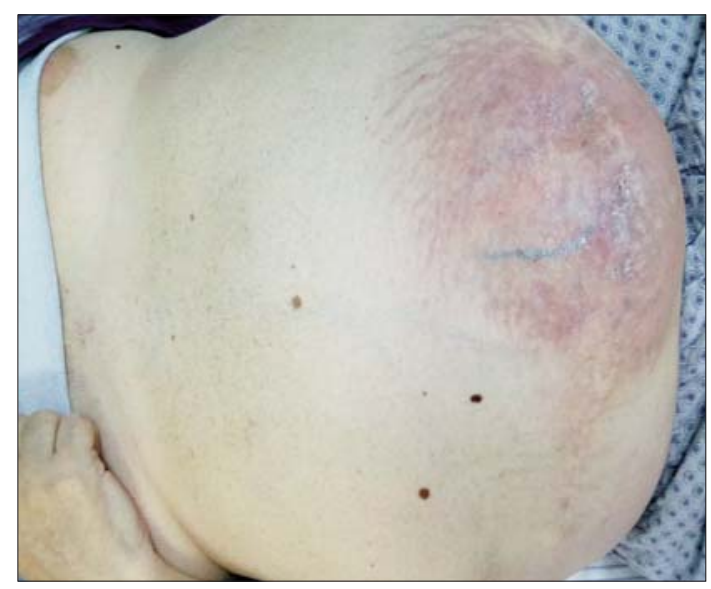

Figure 3. Incisional hernia in a patient with liver cirrhosis and ascites

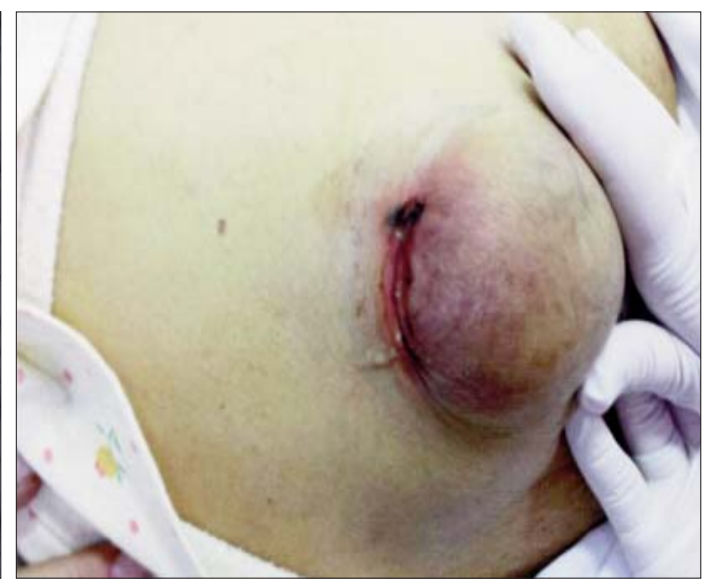

Figure 4. Umbilical hernia in a patient with cirrhosis and ascites 
se does not directly influence the prevalence, leaving aside the other risk factors that the cirrhotic patients develop $(11,12)$.

The volume and recurrence of the ascites positively correlate with the prevalence of the umbilical hernia, reaching $70 \%$ in the third episode of ascites, but also with relapse of the abdominal wall defect. The rate of the hernia recurrence in the presence of ascites reaches $45 \%(13,14)$.

Appropriate control of the ascites significantly improves the results of the hernia surgery in patients with cirrhosis, both in terms of postoperative complications - wound infection, wound dehiscence, peritonitis, and recurrence. Adequate control of ascites reduces hernia recurrence to $4 \%$ (13).

For this, diuretics, hyposodic diet or paracentesis are required. Paracentesis must evacuate small amounts repeatedly, as the sudden and significant reduction in ascites volume can precipitate herniation (11).

For refractary ascites, transjugular intrahepatic portosystemic shunt (TIPS) or temporary peritoneal dialysis may be used $(15,16)$.

Emergency surgery in the presence of ascites, imposed by complications such as strangulation, hernia rupture with ascites leakage or peritonitis, associates a mortality rate of up to $20 \%$ and, at the same time, limits the technical possibilities to solve the lesion. Under these circumstances, the use of alloplastic materials is not indicated due to the very high risk of infection $(17,18)$.

Hepatic cirrhosis is a progressive chronic disease characterized by alteration of the architecture and hepatic function. With the progression of the disease, hepatic dysfunction is associated with complex systemic dysfunctions. The cirrhotic patient may have renal insufficiency, cardio-pulmonary dysfunction, diabetes mellitus, immune deficiency, clotting disorders and malnutrition.

These correlated anomalies create the premise of a load-bearing operation with often unsatisfactory results.

Post-operative care complications may be related to the underlying disease (encephalopathy, aggravation of ascites, upper digestive haemorrhage, coagulopathy, hepato-renal syndrome) but may also be general (ARDS acute respiratory distress syndrome, heart failure, myocardial ischemia), to which can be added those of the surgical wound (infection, dehiscence, bleeding) $(19,20)$.

The results of the surgery on the cirrhotic patient correlate with both the stage of the disease and the amplitude and duration of the surgery, the mean mortality rate varying from $8.3 \%$ to $25 \%$ (18).

Within the category of small amplitude interventions, herniorrhaphy in cirrhotic patients may be associated with the moderate risk class $(21,22)$.

To estimate the risk of the surgical intervention in cirrhosis, a staging of the disease is required. This can be done using the Child Class or the MELD (Model For End-Stage Liver Disease) score.

The arguments in favor for the MELD score are related to the fact that it only uses objective parameters - serum bilirubin, creatinine and the international normalized ratio (INR), while providing an evaluation of the renal function. The results of the non-hepatic surgery reported to this score indicate a good statistical concordance, making it a valid predictor of the postoperative mortality at 30, 90 days and over the long term $(23,24)$.

On the other hand, among the five parameters of the Child scale, two, encephalopathy and ascites, although subjective, correlate with the frequency of the postoperative complications - hepatic failure, renal failure, worsening of ascites, hypoxia and infection.

Mortality in non-hepatic surgery in relation to the Child staging system is estimated at $10 \%$ for Child A, 30\% for Child B and up to $82 \%$ for Child C (25-28).

Although there are currently discussions about the prediction ability of the postoperative results of the two scores, they do not exclude eachother, but are complementary, and in clinical practice it is more useful to calculate both (29).

For patients in Child A stage and elective hernia surgery, encouraging results with minor postoperative complications (wounds, transient 
increase in pre-natal azotomy, reversible moderate encephalopathy), a relapse rate of $8 \%$ and a mortality of $5.7 \%$ have been registered (30).

On a group of 53 patients, Park et al. reported a single postoperative death in a Child $\mathrm{C}$ stage patient, and no recurrence, even in the presence of refractory ascites (31).

Analyzing the results of the herniorrhaphy in 50 patients on waiting list for liver transplantation, Silva et al. found a significant increase in morbidity, from $26.8 \%$ to $66.7 \%$ for a MELD score of 20. Referring to the Child Pugh classes, the morbidity rises from 2/15 for Child A, to 6/23 for Child B and 8/12 for Child C. Four deaths were recorded in Child $\mathrm{C}$ and one in Child B (2).

One of the major problems of the hernia surgery in cirrhotic patients remains relapse. The weakening of the musculo-fascial structures of the abdominal wall and the presence of ascites are the main risk factors for relapsing, non-attributable to the surgical act, that the cirrhotic patient presents (32).

Analyzing the results after umbilical herniorrhaphy on two groups of cirrhotic patients, Runyon reports clear different outcomes between patients with and without ascites at the time of surgery. In those without ascites, the recurrence rate was $12 \%$, while the presence of the ascites at the time of intervention raised the rate of relapse to 73 (33).

In hernia surgery, regarding the long term results, the use of prostheses has led to a significant progress, but its implementation has been looked at cautiously, given the risks associated with it (occlusion, infection, adhesions to the intestine with high risk of fistula, etc.)(34).

The promoter of the hernioplasty is Sarit, who in 2003, using the minimal invasive technique, placed a dual mesh prosthesis in a patient with incarcerated umbilical hernia and ascites Child B. The result was very good, without postoperative complications and without relapse (35).

In the treatment of complicated umbilical hernia, Ammar compares the results of conventional hernirrhaphy with polypropylene hernioplasty in two groups of 40 patients with equivalent Child Staging. The results indicate a lower recurrence rate and a minimal morbidity rate after using the alloplastic technique (36).

Regarding the positioning of the mesh, although there is still no consensus, when the local situation allows it, sublay placement is preferable, offering the least number of complications and relapses (37).

On 70 umbilical hernias in patients with liver cirrhosis and ascites undergoing elective hernia surgery using retromuscular sublay mesh placement, Hassan et al. report 2 wound infections $(2.9 \%), 3$ seromas $(4.3 \%)$, one recurrence (1.4\%) and two deaths $(2.9 \%)(38)$.

For inguinal hernia, the results are satisfactory, both for herniorrhaphy and for the use of alloplastic techniques.

In 22 inguinal hernias operated in patients with cirrhosis and ascites (Child B and C classes), Hur et al. report an average hospital stay of 1.8 days, two cases of postoperative hematomas, one scrotal edema, no recurrence and no deaths at 30 days. The author pays attention to the hernia pouch, which he isolates and inverts using mesh plug technique, thus preventing postoperative ascites leakage. All interventions were performed under local anesthesia, thus causing a minor anesthetic impact on patients with poor hepatic function (39).

$\mathrm{Oh} \mathrm{HK}$ et al. uses the McVay technique in 129 patients with cirrhosis and acites and finds a recurrence rate of $2.3 \%$, similar to noncirrhotic patients (40).

The laparoscopic approach brings a series of advantages for the cirrhotic patient: small incisions that allow the avoidance of dilated collateral venous damage and reduction of blood loss; electrolyte and protein losses are diminished, postoperative pain is lower, recovery is faster, and a better absorption of the ascites, in comparison to the open technique. To avoid ascites leakage through the trocar incisions, they recommend inserting the trocars through the abdominal wall in an oblique plane, decoupling the peritoneus to the muscular and cutaneous planes.

On 14 consecutive incisional and umbilical hernias managed by laparoscopic methods, 
Belli et al. reported an average hospitalization of 2.6 days, minimal postoperative complications, and no recurrence on 8 months follow-up (41).

Giulio compares the results of the laparoscopic treatment with those of the open surgery in umbilical and incisional hernia repair, showing clear differences that favor the laparoscopic technique which associates lower morbidity and recurrence rates (42).

\section{Emergency vs elective surgery}

Emergency surgery in cirrhotic patients is followed by complications and a significantly higher mortality rate compared to the elective surgery.

In a 1993 report by the French Association of Surgery on 81 umbilical hernia in patients with liver cirrhosis undergoing surgical treatment, a $11 \%$ mortality rate was observed for emergency operations, compared with $2 \%$ mortality rate for elective operations.

More recently, Andraus et al. analyzes a heterogeneous group of 61 cirrhotic patients with 74 interventions for different types of hernia of the abdominal wall (umbilical, inguinal, epigastric, perineal and incisional). Emergency surgery was indicated in hernia ulceration, strangulation, or incarcerated. The average hospitalization stay was 13 days for patients treated by emergency surgery compared to 5 days in the elective surgery group. The ratio of severe postoperative complications, grades III-IV according to the Clavien-Dindo classification, was 13:2 for the first category, and the number of deaths was $10(29.4 \%)$ out of the 34 patients from the first group, and $1(3.7 \%)$ out of the 27 patients from the second group (18).

Complications that occur after emergency surgery in cirrhotic patients are related to the type of surgical intervention, the type of anesthesia and the evolutionary stage of the disease, and are mainly represented by hepatic failure, renal failure, bleeding, encephalopathy and worsening of ascites (43).

\section{Conclusions}

The parietal defects of the cirrhotic patients can be surgically approached with satisfactory results. The best results are obtained in patients who are subjected to elective surgery and in compensated stages of the cirrhosis. The technical ways of curing these hernias are represented by both herniorrhaphy and the use of alloplastic materials.

Conservative management is indicated in patients with uncomplicated hernias and in the decompensated stages of the disease.

\section{Conflict of Interest}

The authors declare no conflicts of interests.

\section{References}

1. Ecker BL, Bartlett EK, Hoffman RL, Karakousis GC, Roses RE, Morris JB, Kelz RR. Hernia repair in the presence of ascites. J Surg Res. 2014;190 (2):471-477.

2. Silva FD, Andraus W, Pinheiro RS, Arantes-Junior RM, Lemes MP, Ducatti Lde S, et al. Abdominal and inguinal hernia in cirrhotic patients: what's the best approach? Arq Bras Cir Dig. 2012;25(1): 52-5. English, Portuguese

3. Hansen JB, Thulstrup AM, Vilstup H, Sørensen HT. Danish nationwide cohort study of postoperative death in patients with liver cirrhosis undergoing hernia repair. Br J Surg. 2002;89(6):805-6.

4. Patti R, Almasio PL, Buscemi S, Fama F, Craxi A, Di Vita G. Inguinal hernioplasty improves the quality of life in patients with cirrhosis. Am J Surg. 2008;196(3):373-8.

5. Marsman HA, Heisterkamp J, Halm JA, Tilanus HW, Metselaar HJ, Kazemier G. Management in patients with liver cirrhosis and an umbilical hernia. Surgery. 2007;142(3):372-5.

6. Baron HC. Umbilical hernia secondary to cirrhosis of the liver. Complications of surgical correction. N Engl J Med. 1960;263: 824-8.

7. Carbonell AM, Wolfe LG, DeMaria EJ. Poor outcomes in cirrhosisassociated hernia repair: a nationwide cohort study of 32033 patients. Hernia. 2005;9(4):353-7.

8. Gray SH, Vick CC, Graham LA, Finan KR, Neumayer LA, Hawn MT. - Umbilical herniorrhapy in cirrhosis: improved outcomes with elective repair. J Gastrointest Surg. 2008;12(4):675-81

9. Oh HK, Kim H, Ryoo S, Choe EK, Park KJ. Inguinal hernia repair in patients with cirrhosis is not associated with increased risk of complications and recurrence. World J Surg. 2011;35(6):1229-33.

10. Yu BC, Chung M, Lee $\mathrm{G}$. The repair of umbilical hernia in cirrhotic patients: 18 consecutive case series in a single institute. Annals of Surgical Treatment and Research. 2015;89(2):87-91.

11. Belghiti J, Durand F. Abdominal wall hernias in the setting of cirrhosis, Semin Liver Dis. 1997;17(3):219-26.

12. Ecker BL, Bartlett EK, Hoffman RL, Karakousis GC, Roses RE, Morris JB, et al. Hernia repair in the presence of ascites. J Surg Res 2014;190 (2):471-7.

13. McKay A, Dixon E, Bathe O, Sutherland F. Umbilical hernia repair in 
the presence of cirrhosis and ascites: results of a survey and review of the literature. Hernia. 2009;13(5):461-8.

14. Ammar SA. Management of complicated umbilical hernias in cirrhotic patients using permanent mesh: randomized clinical trial. Hernia. 2010;14(1):35-8.

15. Telem DA, Schiano T, Divino CM. Complicated hernia presentation in patients with advanced cirrhosis and refractory ascites: management and outcome. Surgery. 2010;148(3):538-43.

16. Coelho JC, Claus CM, Campos AC, Costa MA, Blum C. Umbilical hernia in patients with liver cirrhosis: A surgical challenge. World J Gastrointest Surg. 2016;8(7):476-82.

17. Chatzizacharias NA, Bradley JA, Harper S, Butler A, Jah A, Huguet E, Praseedom RK, et al. Successful surgical management of ruptured umbilical hernias in cirrhotic patients. World J Gastroenterol. 2015 21(10):3109-13.

18. Andraus W, Pinheiro RS, Lai $Q$, Haddad LBP, Nacif LS D'Albuquerque LAC, et al. Abdominal wall hernia in cirrhotic patients: emergency surgery results in higher morbidity and mortality. BMC Surg. 2015;15:65.

19. Minemura M, Tajiri K, Shimizu Y. Systemic abnormalities in liver disease. World J Gastroenterol. 2009;15(24):2960-74.

20. Millwala F, Nguyen GC, Thuluvath PJ. Outcomes of patients with cirrhosis undergoing non-hepatic surgery: Risk assessment and management. World J Gastroenterol. 2007;13(30):4056-63.

21. Keegan MT, Plevak DJ. Preoperative assessment of the patient with liver disease. Am J Gastroenterol. 2005;100(9):2116-27.

22. Copeland GP. The POSSUM System of Surgical Audit. Arch Surg 2002;137(1):15-19.

23. Teh SH, Nagorney DM, Stevens SR, Offord KP, Therneau TM Plevak DJ, et al. Risk factors for mortality after surgery in patients with cirrhosis. Gastroenterology. 2007;132(4):1261-9.

24. Northup PG, Wanamaker RC, Lee VD, Adams RB, Berg CL. Mode for End-Stage Liver Disease (MELD) predicts nontransplant surgical mortality in patients with cirrhosis. Ann Surg. 2005; 242(2):244-51.

25. Child CG. Surgery and portal hypertension. In: Child CG, ed. The Liver and Portal Hypertension. Philadelphia, PA: WB Saunders; 1964. p. $50-72$

26. Mansour A, Watson W, Shayani V, Pickleman J. Abdominal operations in patients with cirrhosis: still a major surgical challenge. Surgery. 1997;122(4):730-5

27. Garrison RN, Cryer HM, Howard DA, Polk HC Jr. Clarification of risk factors for abdominal operations in patients with hepatic cirrhosis. Ann Surg. 1984;199(6):648-55.

28. Friedman LS. Surgery in the patient with liver disease. Transactions of the American Clinical and Climatological Association.
2010;121:192-205

29. Bhangui P, Laurent A, Amathieu R, Azoulay D. Assessment of risk for non-hepatic surgery in cirrhotic patients. J Hepatol. 2012; 57(4):874-84

30. Hurst RD, Butler BN, Soybel DI, Wright HK. Management of groin hernias in patients with ascites. Ann Surg. 1992;216(6):696-700.

31. Park JK, Lee SH, Yoon WJ, Lee JK, Park SC, Park BJ, et al. Evaluation of hernia repair operation in Child-Turcotte-Pugh class $\mathrm{C}$ cirrhosis and refractory ascites. 2007; 22(3):377-82.

32. Sorensen LT, Jorgensen LN. Non-surgical risk factors for recurrence of hernia. In: Schumpelick V, Fitzgibbons RJ (eds) Recurrent hernia. Prevention and treatment. Heidelberg: Springer; 2007. p 53-58.

33. Runyon BA, Juler GI. Natural history of repaired umbilical hernias in patients with and without ascites. Am J Gastroenterol. 1985; 80(1):38-9.

34. Holihan JL, Nguyen DH, Nguyen MT, Mo J, Kao LS, Liang MK. Mesh location in open ventral hernia repair: a systematic review and network meta-analysis. World J Surg. 2016;40(1):89-99.

35. Sarit C, Eliezer A, Mizrahi S. Minimally invasive repair of recurrent strangulated umbilical hernia in cirrhotic patient with refractory ascites. Liver Transpl. 2003;9(6):621-2.

36. Ammar SA. Management of complicated umbilical hernias in cirrhotic patients using permanent mesh: randomized clinical trial. Hernia. 2010;14(1):35-8.

37. Vichová B, Oravský M, Schnorrer M. Scar hernia repairs using a mesh - the sublay technique. Rozhl Chir. 2008;87(3):138-40. Slovak

38. Hassan AM, Salama AF, Hamdy H, Elsebae MM, Abdelaziz AM, Elzayat WA. Outcome of sublay mesh repair in non-complicated umbilical hernia with liver cirrhosis and ascites. Int J Surg. 2014; 12(2):181-5.

39. Hur YH, Kim JC, Kim DY, Kim SK, Park CY. Inguinal hernia repair in patients with liver cirrhosis accompanied by ascites. Journal of the Korean Surgical Society. 2011;80(6):420-425.

40. Oh HK, Kim H, Ryoo S, Choe EK, Park KJ. Inguinal hernia repair in patients with cirrhosis is not associated with increased risk of complications and recurrence. World J Surg. 2011;35(6):1229-33.

41. Belli G, D'Agostino A, Fantini C, Cioffi L, Belli A, Russolillo N, et al. Laparoscopic incisional and umbilical hernia repair in cirrhotic patients. Surg Laparosc Endosc Percutan Tech. 2006;16(5):330-3.

42. Guilio B, Alberto D, Corrado F, Luigi C, Andrea B, Nadia R, et al. Laparoscopic incisional and umbilical hernia repair in cirrhotic patients. Surg Laparosc Endosc Percutan Tech. 2006;16(5):330-3.

43. Farnsworth N, Fagan SP, Berger DH, Awad SS. Child-Turcotte-Pugh versus MELD score as a predictor of outcome after elective and emergent surgery in cirrhotic patients., Am J Surg. 2004;188(5): 580-3. 